\title{
MAXIMUM ACCEPTABLE TEMPERATURES \\ OF WASTES AND CONTAINERS DURING RETRIEVABLE GEOLOGIC STORAGE
}

\author{
G. H. Jenks
}

August 17, 1977

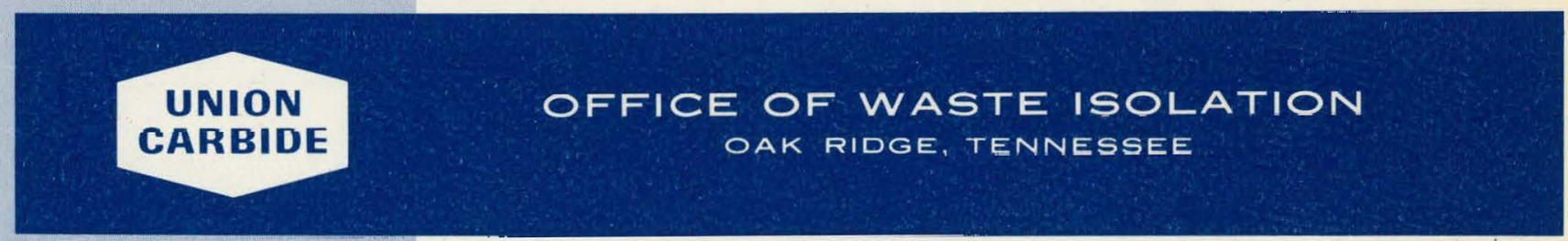

prepared for the U.S. ENERGY RESEARCH AND DEVELOPMENT ADMINISTRATION under U.S. GOVERNMENT Contract W-7405 eng 26 


\section{DISCLAIMER}

This report was prepared as an account of work sponsored by an agency of the United States Government. Neither the United States Government nor any agency Thereof, nor any of their employees, makes any warranty, express or implied, or assumes any legal liability or responsibility for the accuracy, completeness, or usefulness of any information, apparatus, product, or process disclosed, or represents that its use would not infringe privately owned rights. Reference herein to any specific commercial product, process, or service by trade name, trademark, manufacturer, or otherwise does not necessarily constitute or imply its endorsement, recommendation, or favoring by the United States Government or any agency thereof. The views and opinions of authors expressed herein do not necessarily state or reflect those of the United States Government or any agency thereof. 


\section{DISCLAIMER}

Portions of this document may be illegible in electronic image products. Images are produced from the best available original document. 
This report was prepared as an account of work sponsored by the United States Government. Neither the United States nor the Energy Research and Development Administration, nor any of their employees, nor any of their contractors, subcontractors, or their employees, makes any warranty, express or implied, or assumes any legal liability or responsibility for the accuracy, completeness or usefulness of any information, apparatus, product or process disclosed, or represents that its use would not infringe privately owned rights. 
MAXIMUM ACCEPTABLE TEMPERATURES OF WASTES AND CONTAINERS

DURING RETRIEVABLE GEOLOGIC STORAGE

by

G. H. Jenks

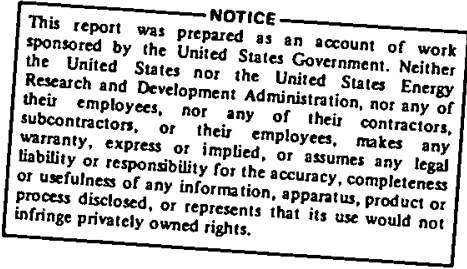

Abstract

Estimates of maximum acceptable temperatures of waste and containers during retrievable geologic storage were needed for use in evaluating and comparing conceptual designs for repositories for wastes from reprocessing and for spent fuel in several different rock types. Estimates of these temperatures and discussions of the bases for the estimates are presented.

\section{Introduction}

Estimates of maximum acceptable temperatures of waste and containers during retrievable geologic storage are listed in Table 1 . These were made for use in evaluating and comparing conceptual designs for repositories in several different rock types. General assumptions regarding the office of Waste Isolation concept of retrievability, the length of the period of retrievability, and the container materials are discussed below. These formed partial bases for the estimated temperatures. More specific comments on the bases for the estimates for each of the waste types are given in the subsequent text as notes to Table 1.

\section{Retrievability Concept}

The wastes that are emplaced in a repository will be encapsulated in suitable metal canisters. These canisters must be readily retrievable for predesignated periods of time after emplacement. "Readily retrievable" means that a given canister can be removed and transported to surface facilities with approximately the same effort and time that were required. for the emplacement. It also implies that the canister can be safely stored in appropriate surface facilities for several months after retrieva?.

The canisters will be protected from contact with any vapors which might lead to failure of the containment during the period of retrievability. In order to achieve this protection, it may be necessary to use an overpack comprised of a more corrosion-resistant metal than that used in the canister. For example, if the corrosion environment is such that austenitic stainless steel high-level-waste canisters would undergo stress corrosion cracking, it would be necessary to use an overpack of a metal that does not crack in the environments, e.g., carbon stee 1 in an aqueous chloride environment. On the other hand, if the waste form itself comprises an adequate containment in the environments, it would not be necessary to assure that the canister remains intact. For example, lowlevel TRU wastes that are incinerated and then made into a glass would probably be adequately protected by the glass alone. 


\section{Period of Retrievability}

The assumed length of the retrievability period is five years for a11 wastes. except spent fuel. The assumed period for the spent fuel is 25 years.

\section{Container Material}

Austenitic stainless steel, 304L, is the assumed container material for high-level waste, and either austenitic stainless steel or carbon steel is assumed for the other wastes.

Table 1. Maximum Acceptable Temperature of Waste and Container during Retrievable Geologic Storage

\begin{tabular}{|c|c|c|}
\hline Item & $\begin{array}{c}\text { Maximum acceptable } \\
\text { temperature }\left({ }^{\circ} \mathrm{C}\right)\end{array}$ & $\begin{array}{l}\text { Note } \\
\text { number }\end{array}$ \\
\hline $\begin{array}{l}\text { High-level waste } \\
\text { Canister } \\
\text { Solid waste } \\
\text { Glass } \\
\text { Calcine } \\
\text { Sintered glass ceramic }\end{array}$ & $\begin{array}{l}375 \\
500 \\
700 \\
800\end{array}$ & $\begin{array}{l}1 \\
2 \\
3 \\
4\end{array}$ \\
\hline $\begin{array}{c}\text { Cladding and hardware } \\
\text { Canister } \\
\text { Solid waste } \\
\text { Compressed } \\
\text { Fused }\end{array}$ & $\begin{array}{l}375 \\
200 \\
400\end{array}$ & $\begin{array}{r}1,5 \\
6 \\
7\end{array}$ \\
\hline $\begin{array}{l}\text { Intermediate-level transuranic wast } \\
\text { Canister } \\
\text { Solid waste } \\
\text { Glass }\end{array}$ & $\begin{array}{l}375 \\
500\end{array}$ & $\begin{array}{l}1,5 \\
2,5\end{array}$ \\
\hline $\begin{array}{c}\text { Low-level transuranic waste } \\
\text { Canister } \\
\text { Solid waste } \\
\text { Glass } \\
\text { Cement }\end{array}$ & $\begin{array}{l}375 \\
500 \\
110\end{array}$ & $\begin{array}{r}5 \\
2,5 \\
8\end{array}$ \\
\hline Spent fuel element & 200 & 9 \\
\hline $\mathrm{PuO}_{2}$ & 500 & 5,10 \\
\hline
\end{tabular}




\section{Notes to Table 1}

1. Austenitic stainless steel undergoes changes in structure during long-term exposures in air at temperatures in the range of 400 to $900^{\circ} \mathrm{C}$. The observed effect is an increased susceptibility to stress cracking upon subsequent exposure to water at atmospheric temperatures. I Pacific Northwest Laboratories workers have stated that precautions should be taken to maintain the canister wall temperatures below $400^{\circ} \mathrm{C}$ during handling and storage after filling, in order to avoid this sensitization. Argonne National Laboratory workers have quoted a maximum temperature of $343^{\circ} \mathrm{C}$ $\left(650^{\circ} \mathrm{F}\right)$ for 100 -year retrievable storage in air. ${ }^{2}$ Atlantic Richfield Hanford Company workers ${ }^{3}$ have recently recommended maximum temperatures of $277^{\circ} \mathrm{C}\left(530^{\circ} \mathrm{F}\right)$ and $427^{\circ} \mathrm{C}\left(800^{\circ} \mathrm{F}\right)$, respectively, for normal and abnormal conditions in long-term (100-year) retrievable, sealed cask storage. The abnormal conditions could presumably prevail for an indefinite period. I have concluded that the limit of $375^{\circ} \mathrm{C}$ for 5 -year retrievable geologic storage is reasonable, especially since the canister will probably be at the maximum temperature for not more than about 1 year.

Carbon steel is probably less susceptible to significant changes in structure and corrosion susceptibility during long-term heating at temperatures $\geq 400^{\circ} \mathrm{C}$, but there is no information on this. Accordingly, I have specified the same temperature limit as that for stainless steel.

2. The transition temperature for typical borosilicate waste glasses is about $500^{\circ} \mathrm{C} .{ }^{4}$ The softening temperature is a few degrees higher. 4 Significant increases in cracking and in leach rates have been observed in test glasses that were heated for periods of a few months in the temperature range 500 to $800^{\circ} \mathrm{C} .{ }^{1,5}$ Migration of heavy, separate phases in the glass might take place above the softening temperature. This could be of special concern with that part of high-level waste from uranium-onlyrecycle which contains most of the plutonium that was generated during reactor operation. The solubility of plutonium in a waste glass may be only about $2 \%$ by weight, 6 in which case about $50 \%$ of this plutonium would occur as a separate phase in the glass. Hoskins and Berreth ${ }^{7}$ have suggested $550^{\circ} \mathrm{C}$ for the maximum temperature of waste glass during storage.

Considerations of the above information have led me to propose $500^{\circ} \mathrm{C}$ for the maximum temperature to which borosilicate waste glass should be exposed during retrievable geologic storage.

3. This is the limit value suggested by Hoskins and Berreth ${ }^{7}$ on the basis that significant cesium volatility occurs at temperatures greater than $750^{\circ} \mathrm{C}$.

4. This is the value suggested by Hoskins and Berreth ${ }^{7}$ on the bas is of preliminary evidence that this material is stable to at least $800^{\circ} \mathrm{C}$.

5. These wastes will have relatively low heat production rates, and the maximum temperatures will probably be less than this limit value.

6. This limit value is based on the following considerations: The surfaces of the Zircaloy hulls may become very reactive during storage within a sealed canister as a result of the degradation of the protective 
oxide film which will occur during heating in the absence of an oxidant.8-10 No complete analyses have been made of hazards that might result from the above effects and how these would depend upon the temperatures in the contained wastes.

My rough guess is that $200^{\circ} \mathrm{C}$ is a reasonably conservative maximum temperature for these cladding and hardware wastes. Additional work is. needed to arrive at firmer estimates of reasonable temperature limits.

7. The surface area-to-volume ratio of these fused wastes will be much less than that for the compressed wastes, and, accordingly, the possibilities of encountering significant hazards from rapid surface reactions will be much less for the fused wastes. I believe that the $400^{\circ} \mathrm{C}$ limit is reasonably conservative. Additional work is needed to arrive at firmer estimates of reasonable temperature limits.

8. I do not have any good basis for estimating acceptable temperatures for concrete. Atlantic Richfield Hanford Company workers ${ }^{3}$ have recently recommended maximum temperatures of 110 and $165^{\circ} \mathrm{C}$, respectively, for normal and abnormal conditions in structural concrete in long-term (100-year) surface storage of high-level waste. The abnormal conditions presumably could prevail for an indefinite period. I have assumed their value for normal operation. Additional work is needed to arrive at better estimates of reasonable temperature limits, if there is any incentive for use of higher temperatures in the concrete.

9. The considerations which led to this temperature limit are the same as those set out under note 6 above. Additional work is needed to arrive at firmer estimates of reasonable temperature limits for the spent fuel.

10. High-fired $\left(1000^{\circ} \mathrm{C}\right) \mathrm{PuO}_{2}$ is very refractory and is difficult to dissolve by normal techniques. 11 Also, its vapor pressure is very low $\left(<<10^{-10} \mathrm{~atm}\right.$ at $\left.500^{\circ} \mathrm{C}\right) .11$. Accordingly, the stated 1 imit of $500^{\circ} \mathrm{C}$ in Table 1, which will not be reached in practice with emplacement in a geologic repository, appears conservative.

\section{References}

1. Mendel, J. E., "High-Level Waste Glass," Nucl. Technol. 32(1), 72-87 (1977).

2. Mecham, W. J.; Seefeldt, W. B.; and Steindler, M. J.; An Analysis of Factors Influencing the Reliability of Retrievable Storage Canisters for Containment of Solid High-Level Radioactive Waste, Argonne National Laboratory, ANL-76-82 (August 1976).

3. Retrievable Surface Storage Facility Conceptual System Design Description, Atlantic Richfield Hanford Company and Kaiser Engineers, ARH-LD-140 Rev., Informal Report (March 1977), pp. 3-12. 
4. Roberts, F. P.; Jenks, G. H.; and Bopp, C. D.; Radiation Effects in Solidified High-Level Waste, Part I, Stored Energy, Battelle, Pacific Northwest Laboratories, BNll-1944 (January 1976).

5. Mendel, J. E., et al., Annual Report on the Characterization of High-Level Waste Glass, Battelle, Pacific Northwest Laboratories, BNWL-2252 (June 1977).

6. Scheffler, K.; et a1., Long-Term Leaching of Silicate Systems:

Testing Procedure, Actinides Behaviour and Mechanism, Gesellschaft fuer Kernforschung m.B.H., Karlsruhe, KFK-2456 (May 1977).

7. Hoskins, A. P., and Berreth, J. R.., Heat Transfer Considerations in the Canister Storage of High-Level Solidified Wastes, Allied Chemical Corporation, ICP-1090 (Aprit 1976).

8. Cox, B., "Oxidation of Zirconium and Its Alloys," vol. 5, pp. 173-39l in Advances in Corrosion Science and Technology, Fontana, M. G., and Staehle, R. W., editors, Plenum Press, 1976.

9. Gulbransen, E. A., and Andrew, K. F., "Mechanism of the Reaction of Hydrogen with Zirconium I. Role of Oxide Films, Pretreatments, and Occluded Gases," J. Electrochem. Soc. 101, 348-53 (1954).

10. Pemsier, J. P., The Diffusion of Oxygen in Zirconium and Its Relation to Oxidation and Corrosion, Nuclear Metals, Inc., NMI-1177 (May 31, 1957).

11. Cleveland, J. M.., The Chemistry of Plutonium, Gordon and Breach, pp. 291-301, 1970. 
DISTRIBUTION

Office of Waste Isolation
A. L. Boch
G. D. Brunton
H. C. Claiborne
L. R. Dole
P. D. Fairchild
W. A. Goldsmith
I. N. Kaplan
R. K. Kibbe
R. B. Laughon
T. F. Lomenick
R. S. Lowrie
S. C. Matthews
L. L. McCauley
W. C. McClain
J. M. Morrison
A. S. Quist
H. N. Rosenberg
J. E. Russell
R. L. Shoup
J. E. Vath
C. D. Zerby
OWI Records - 25 